\title{
Appendiceal Carcinoma Clinical TNM Finding v8
}

National Cancer Institute

\section{Source}

National Cancer Institute. Appendiceal Carcinoma Clinical TNM Finding v8. NCI

Thesaurus. Code C134040.

A clinical finding about one or more characteristics of appendiceal carcinoma, following the rules of the TNM AJCC V8 classification system. 